\title{
Nitrogen-fixation by the cyanobacterial symbiont of the diatom genus Hemiaulus
}

\author{
Tracy A. Villareal* \\ Woods Hole Oceanographic Institution, Woods Hole, Massachusetts 02543, USA
}

\begin{abstract}
Nitrogen-fixation by cyanobacterial symbionts in the oceanic diatoms Hemiaulus membranaceus, H. hauckii, and $H$. sinensis was documented in the Southwestern Atlantic Ocean. All Hemiaulus cells with diatom chlorophyll autofluorescence contained fluorescent symbionts undetectable by standard light microscopy. Average cell-specific ethylene reduction rates $\left(2.3\right.$ to $5.3 \times 10^{-13} \mathrm{M}$ ethylene cell $\left.\mathrm{h}^{-1}\right)$ were 2.2 to 5.2 times lower than calculated rates from Rhizosolenia. Richelia blooms in the central Pacific gyre and 26 times lower than results from Richelia-containing Rhizosolenia cultures. Calculations suggest that the $\mathrm{N}_{2}$ fixation associated with Hemiaulus is 21 to 45 times greater than that from the Rhizosolenia-Richelia association in the southwestern Atlantic Ocean.
\end{abstract}

Hemiaulus is a common and ubiquitous diatom genus typically dominating or co-dominating the diatom community after seasonal stratification in warm oligotrophic seas (Guillard \& Kilham 1977). A puzzling aspect of its ecology is its persistence over large areas dominated by nano- and pico-plankton despite low ambient nutrients. Periodic blooms of this genus occur in the central Pacific gyre and have been associated with the nitrogen-fixing Rhizosolenia-Richelia symbiosis (Venrick 1974). Cyanobacterial symbionts usually identified as Richelia intracellularis Schmidt are also known in Hemiaulus; however, the identity of the symbiont is uncertain (Sundström 1984). The presence of a heterocyst suggests $\mathrm{N}_{2}$-fixation is likely in this symbiosis (Kimor et al. 1978, Heinbokel 1986), but $\mathrm{N}_{2}$-fixation by Hemiaulus symbionts has never been examined.

- Current address: Environmental Sciences Program, University of Massachusetts, Boston Harbor Campus, Boston, Massachusetts 02125-3393, USA
Although the host is frequently seen, the symbiont is rarely reported. Kimor et al. (1978) noted that up to $62 \%$ of the Hemiaulus membranaceus Cleve collected off southern California contained symbionts, although more extensive collections offshore contained only 16.1 to $18.6 \%$ symbiotic Hemiaulus. Heinbokel (1986) noted that the Hemiaulus symbionts were frequently visible only under epifluorescent illumination, and that ca $80 \%(\mathrm{n}=668)$ of the Hemiaulus hauckii and H. membranaceus in samples north of Hawail contained symbionts. He suggested that symbiont abundance, and their role in oceanic nitrogen fixation, may have been underestimated due to the need to use epifluorescence to reliably identify the symbiont. In this report, I document $\mathrm{N}_{2}$-fixation by the Hemiaulus symbioses, and present some additional observations on the cryptic nature of the symbiont.

Methods and materials. Hemiaulus cells were isolated by micropipet from surface tows $(30 \mathrm{~cm}$ net, $20 \mu \mathrm{m}$ mesh) north of St. Johns, U.S. Virgin Islands (13 Feb 1991; $18^{\circ} 36.43^{\prime} \mathrm{N}, 65^{\circ} 27.49^{\prime} \mathrm{W}$ ), and north

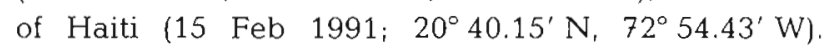
Hemiaulus cells (130 to 200 each) were placed into $2 \mathrm{ml}$ screwcap vials equipped with a Teflon lined septum and containing $1 \mathrm{ml}$ of $0.45 \mu \mathrm{m}$ filtered seawater. Care was taken to exclude trichomes of Trichodesmium and cells of Richelia-containing Rhizosolenia from the vials. Curved chains of $H$. hauckii were present, but were not examined for acetylene reduction due to the difficulty in picking the chains with the micropipet. A blank of filtered seawater was run concurrently. Vials were incubated at $26^{\circ} \mathrm{C}$ and $306 \mu \mathrm{E} \mathrm{m} \mathrm{m}^{-2} \mathrm{~s}^{-1}$. Two experiments were run with each net tow collection 
and consisted of one vial of $H$. membranaceus and one vial of combined $H$. hauckii and $H$. sinensis. Acetylene was injected $(0.2 \mathrm{ml})$ into the headspace and subsequent ethylene generation was measured on a Shimadzu Mini 2 gas chromatograph. Ethylene concentrations were corrected for liquid-phase solubility, and successive time series points were corrected for the sample volume withdrawn in the previous assays. The small headspace volume $(1 \mathrm{ml})$ precluded replication of time series samples. Rates of ethylene evolution were determined from the slope of the time-series data.

Symbiont enumeration was performed on a Zeiss Axiomat microscope equipped with epifluorescence capabilities using freshly collected samples. Approximately 10 to 100 cells of each species (depending on its abundance) were examined from the same net tow as the acetylene reduction experiments.

Results and conclusions. Ethylene evolution occurred in all experimental vials containing Hemiaulus. Rates of ethylene evolution were linear for at least $4 \mathrm{~h}$ (Fig. 1). H. membranaceus-containing vials evolved ethylene at rates of 2.3 and $3.6 \times 10^{-13} \mathrm{~mol}$ ethylene cell ${ }^{-1} \mathrm{~h}^{-1}$, and $H$. hauckii-H. sinensis evolved ethylene at 3.0 and $5.3 \times 10^{-13} \mathrm{~mol}$ ethylene cell ${ }^{-1} \mathrm{~h}^{-1}$. No symbionts were visible under brightfield or Nomarski illumination; however, under epifluorescence, all Hemiaulus spp. except the curved morph of H. hauckii contained 1 or 2 symbionts (Fig. 2). The curved $H$. hauckii ( $\mathrm{n}=30$ ) showed no host chlorophyll autofluorescence, contained no symbionts, and appeared dead. These observations are similar to Heinbokel's (1986) observations of ca $80 \%$ symbiont-containing Hemiaulus cells north of Hawaii. Although $H$. hauckii and $H$. sinensis were not examined individually for acetylene reduction, it is reasonable to assume the symbionts of both species were fixing nitrogen. Average host cell-specific rates of ethylene evolution for the

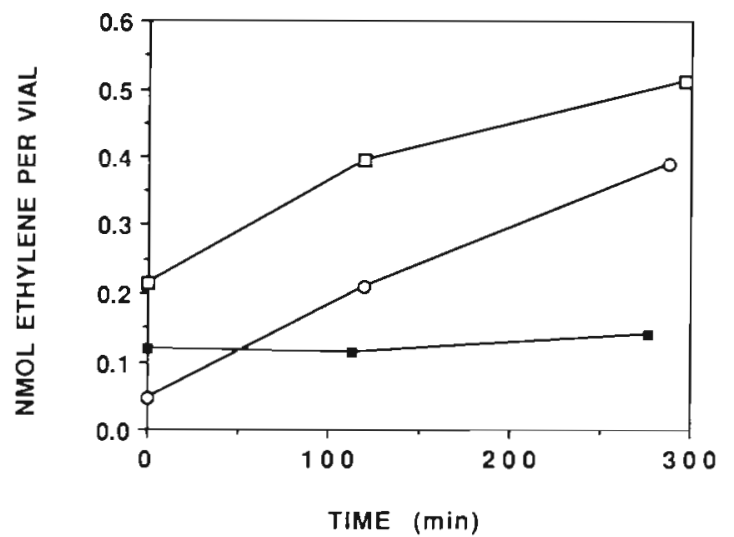

Fig. 1 Time course of ethylene evolution from samples collected on 13 Feb. 1991 ( $)$ Hemiaulus membranaceus; $\Leftrightarrow H$ hauckii-H. sinensis; (-) blank values
Hemiaulus symbioses $\left(3.6 \times 10^{-13} \mathrm{~mol}\right.$ ethylene cell ${ }^{-1}$ $\mathrm{h}^{-\mathrm{t}}$ ) were 2.2 to 5.3 times lower than field rates of ethylene evolution $\left(0.8\right.$ to $1.9 \times 10^{-12} \mathrm{M}$ ethylene trichome $\mathrm{h}^{-1}$ ) calculated by Villareal (1990) for field data of Mague et al. (1974) on Rhizosolenia-Richelia, and were ca 26 times lower than ethylene evolution rates $\left(9.5 \times 10^{-12} \mathrm{M}\right.$ ethylene trichome $\left.h^{-1}\right)$ from laboratory cultures of the Rhizosolenia-Richelia symbiosis at $300 \mu \mathrm{E} \mathrm{m}^{-2} \mathrm{~s}^{-1}$ (Villareal 1990).

The nitrogen fixation by these often cryptic Hemiaulus symbionts is an undocumented new production source. The significance of the nitrogen input can be estimated for the summer central North Pacific gyre where a conservative calculation based on the minimum acetylene reduction rate, a $4: 1$ acetylene reduction $-\mathrm{N}_{2}$ fixation ratio, and a $30 \mathrm{~m}$ vertical $\mathrm{N}_{2}$ fixation zone, suggests that at a typical abundance of 100 cells $^{-1}$ (Venrick unpubl. obs.), Hemiaulus could contribute $4.8 \mu \mathrm{g}$-at. $\mathrm{N} \mathrm{m}^{-2} \mathrm{~d}^{-1}$ or ca $15 \%$ of the average $\mathrm{N}_{2}$ fixation (33 $\mathrm{gg}$-at. $\mathrm{N} \mathrm{m}^{-2} \mathrm{~d}^{-1}$; Mague et al. 1974). Blooms of 25000 Hemiaulus cells $1^{-1}$ are reported in this region (Venrick 1974), and could have an important effect on nutrient dynamics in the region if symbiont nitrogen fixation occurs at similar rates.

It is difficult to address further the quantitative importance symbiotic $\mathrm{N}_{2}$ fixation. Hemiaulus hauckii is capable of up to 3.8 divisions $\mathrm{d}^{-1}$ at $24^{\circ} \mathrm{C}$ in laboratory culture (Brand \& Guillard 1981) while $H$. sinensis may grow at up to 1.99 divisions $d^{-1}$ at $25^{\circ} \mathrm{C}$ (Brand et al. 1983). Field growth rates of 4.3 divisions $\mathrm{d}^{-1}$ for $H$. hauckii and 2.2 divisions $\mathrm{d}^{-1}$ for Hemiaulus spp. have been reported from cage cultures off the west coast of Florida (Vargo 1983) and off the Great Barrier Reef (Furnas 1991), respectively. Like symbiotic Rhizosolenia (Villareal 1990), Hemiaulus probably obtains fixed nitrogen from the symbiont that serves to sustain the host diatom under oligotrophic conditions. Should the symbiont be capable of sustaining these host high growth rates, then explosive inputs of new nitrogen via symbiotic nitrogen-fixation may be occurring in oligotrophic tropical and subtropical seas.

The importance of this question is apparent from the tropical-subtropical distribution of this genus. After seasonal stratification, Hemiaulus can represent one of the dominant diatom taxa in the Sargasso Sea (Hulburt et al. 1960, Hulburt 1966), the Aegean Sea (Ignatiades 1969) and the central Pacific gyre (Venrick 1969). One or 2 Hemiaulus species frequently dominated the diatom flora in the Northwest Providence Channel, Bahamas from 1964 to 1966 (Wood 1968), and it is 'frequent and abundant' (up to 153300 cells $\mathrm{I}^{-1}$ of $H$. sinensis) on the west coast of Florida (Saunders \& Glen 1969.). Near-shore and far-shore average summer abundance of $H$. sinensis is 3924 and 5668 cells $1^{-1}$, respectively, in the Mid-Atlantic Bight region of the 
Fig. 2. Hemiaulus membranaceus chain. (a) Phase contrast illumination. Note that the symbionts are not visible. (b) Epifluorescent illumination. Note that each cell has 2 symbionts. Scale bar $=8 \mu \mathrm{m}$. Photographs courtesy of D. Caron
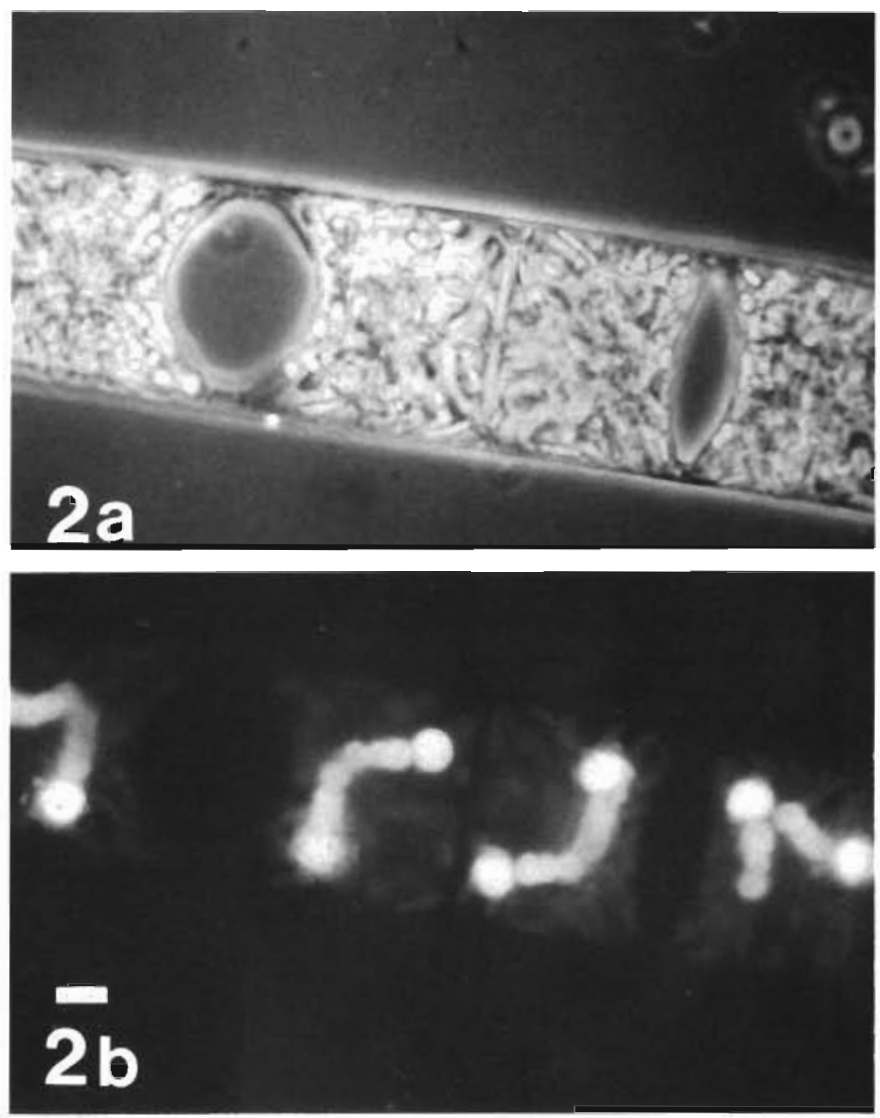

eastern USA (Marshall \& Cohn 1987). It is evident that Hemiaulus is an important and often abundant component of the diatom community.

The distribution of symbionts is more problematic. Hemiaulus spp. are far more abundant than the commonly noted Rhizosolenia-Richelia symbiosis (Gilmartin \& Revelante 1974, Venrick 1971, 1974). For exam-

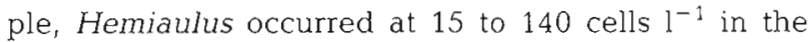
southern and central Sargasso Sea, while RhizosoleniaRichelia was not found (Hulburt et al. 1960, Hulburt 1962). Hargraves et al. (1970) noted that Richelia was present at only 2 of 17 stations in the Lesser Antilles region, but Hemiaulus was present at 13 of 17 stations. The reported symbiosis percentages of Hemiaulus in Heinbokel (1986) and in this study (80 to $100 \%$ ) suggest that symbionts could be present in a large proportion of these cells. In the net collections from this study, only 3 Rhizosolenia-Richelia associations were seen, while over 300 symbiotic Hemiaulus spp. were observed. Based on this relative abundance, the measured field rates of acetylene reduction by their symbionts, and assuming a constant conversion ratio of acetylene reduction: $\mathrm{N}_{2}$ fixation, it appears that 21 to 45 times as much symbiotic $\mathrm{N}_{2}$ fixation was occurring by Hemiaulus associations as by Rhizosolenia associations at the Caribbean study sites.

Current $\mathrm{N}_{2}$-fixation surveys may be missing a sub- stantial fraction of total nitrogen fixation by overlooking these cryptic symbioses. A major unresolved question is whether all Hemiaulus contain symbionts, and the degree to which these symbionts are present in, and contribute to, Hemiaulus bloom formation or maintenance. As a final note, other diatoms are noted to contain coccoid cyanobacterial symbionts that may be capable of $\mathrm{N}_{2}$ fixation (Norris 1967, Hallegraeff \& Jeffery 1984). These symbioses also require further study to examine their contribution to $\mathrm{N}_{2}$ fixation.

Acknowledgements. This work was supported by NSF grant \# OCE 9012199 (D. G. Capone) and OCE 9015606 (E. J. Carpenter). Contribution $\# 7773$ from Woods Hole Oceanographic Institution. I thank J. C. Goldman and J. B. Waterbury for their comments on the manuscript.

\section{LITERATURE CITED}

Brand, L. E., Guillard, R. R. L. (1981). The effects of continuous light and light intensity on the reproduction rates of twenty-two species of marine phytoplankton. J. exp. mar. Biol. Ecol. 50: 119-132

Brand, L. E., Sunda, W. G., Guillard, R. R. L. (1983). Limitation of marine phytoplankton reproductive rates by zinc, manganese, and iron. Limnol. Oceanogr. 28: 1182-1198

Furnas, M. J. (1991). Net in situ growth rates of phytoplankton in an oligotrophic, tropical shelf ecosystem. Limnol. Oceanogr. 36: 13-29 
Gilmartin, M., Revelante, N. (1974). The 'island mass' effect on the phytoplankton and primary production of the Hawaiian Islands. J. exp. mar Biol. Ecol. 16: 181-204

Guillard, R. R. L., Kilham, P. (1977). The ecology of marine planktonic diatoms. In: Werner, D. (ed.) The biology of diatoms. University of California Press, Berkeley, p. 372-469

Hallegraeff, G. M., Jeffery, S. W (1984). Tropical phytoplankton species and pigments of continental shelf waters of North and North-west Australia. Mar. Ecol. Prog. Ser. 20 $59-74$

Hargraves, P. E., Brody, R. W., Burkholder, P. R. (1970). A study of phytoplankton in the Lesser Antilles region. Bull mar Sci. 20: 331-349

Heinbokel, J. F. (1986). Occurrence of Richelia intracellularis (Cyanophyta) within the diatoms Hemiaulus haukii and $H$. membranaceus off Hawaii. J. Phycol. 22: 399-403

Hulburt, E. M. (1962). Phytoplankton in the southwestern Sargasso Sea and North Equatorial Current, February 1961. Limnol. Oceanogr. 7: 307-315

Hulburt, E. M. (1966). The distribution of phytoplankton, and its relationship to hydrography, between southern New England and Venezuela. J. mar. Res. 24:67-81

Hulburt, E. M., Ryther, J. H., Guillard, R. R. L. (1960). The phytoplankton of the Sargasso Sea off Bermuda. J. Cons. int. Explor Mer 25: 115-128

Ignatiades, L. (1969). Annual cycle, species diversity and succession of phytoplankton in lower Saronicos Bay, Aegean Sea. Mar. Biol. 3: 196-200

Kimor, B., Reid, F. M. H., Jordan, J. B. (1978). An unusual occurrence of Hemiaulus membranaceus Cleve (Bacillariophyceae) with Richelia intracellularis Schmidt (Cyanophyceae) off the coast of Southern California in October 1976. Phycol. 17: 162-166

Mague, T H., Weare, N. M., Holm-Hansen, O. (1974). Nitrogen fixation in the North Pacific Ocean. Mar. Biol 24: 109-119

Marshall, H. G., Cohn, M. S. (1987). Phytoplankton distribu-

This note was submitted to the editor tion along the eastern coast of the USA. Part IV. Shelf distribution between Cape Henry and Cape May. J. Plankton Res. 9: 139-149

Norris, R. E. (1967). Algal consortisms in marine plankton. In Krishnamurthy, $V$ (ed.) Proc. Seminar on Sea, Salt and Plants, 1965. Catholic Press, Ranchi (Bihar), India, Central Salt and Marine Chemicals Research Institute, Bhavnagar, India, p. 178-189

Saunders, R. P., Glen, D. A. (1969.). Diatoms. Mem. Hourglass Cruises I. Fla. Dept. Nat. Resources Mar. Res. Lab., St Petersburg, p. 1-119

Sundström, B. G. (1984). Observations on Rhizosolenia clevei Ostenfeld (Bacillariophyceae) and Richelia intracellularis Schmidt. Botanica mar. 27: 345-355

Vargo, G. A. (1983). Growth rates of natural populations of marine diatoms as determined in cage cultures. In: HolmHansen, O., Belle, I., Gilies, R. (eds.) Marine phytoplankton and productivity. Lecture Notes on Coastal and Estuarine Studies. Vol. 8. Springer-Verlag, New York, p $113-127$

Venrick, E. L. (1969). The distribution and ecology of oceanic diatoms in the North Pacific Ph.D. dissertation, University of California, San Diego

Venrick, E. L. (1971). Recurrent groups of diatom species in the North Pacific. Ecology 52: 614-625

Venrick, E. L. (1974). The distribution and significance of Richelia intracellularis Schmidt in the North Pacific Central Gyre. Limnol. Oceanogr 19: 437-445

Villareal, T A. (1990). Laboratory cultivation and preliminary characterization of the Rhizosolenia (Bacillariophyceae)Richelia (Cyanophyceae) symbiosis. P.Z.S.N. I: Mar Ecol. 11: $117-132$

Wood, E. J. F. (1968). Studies of phytoplankton ecology in tropical and subtropical environments of the Atlantic Ocean. Part 3. Phytoplankton communities in the Providence Channels and the Tongue of the Ocean. Bull. mar. Sci. 18: 481-543

Manuscript first received: March 12, 1991

Revised version accepted: July 5, 1991 